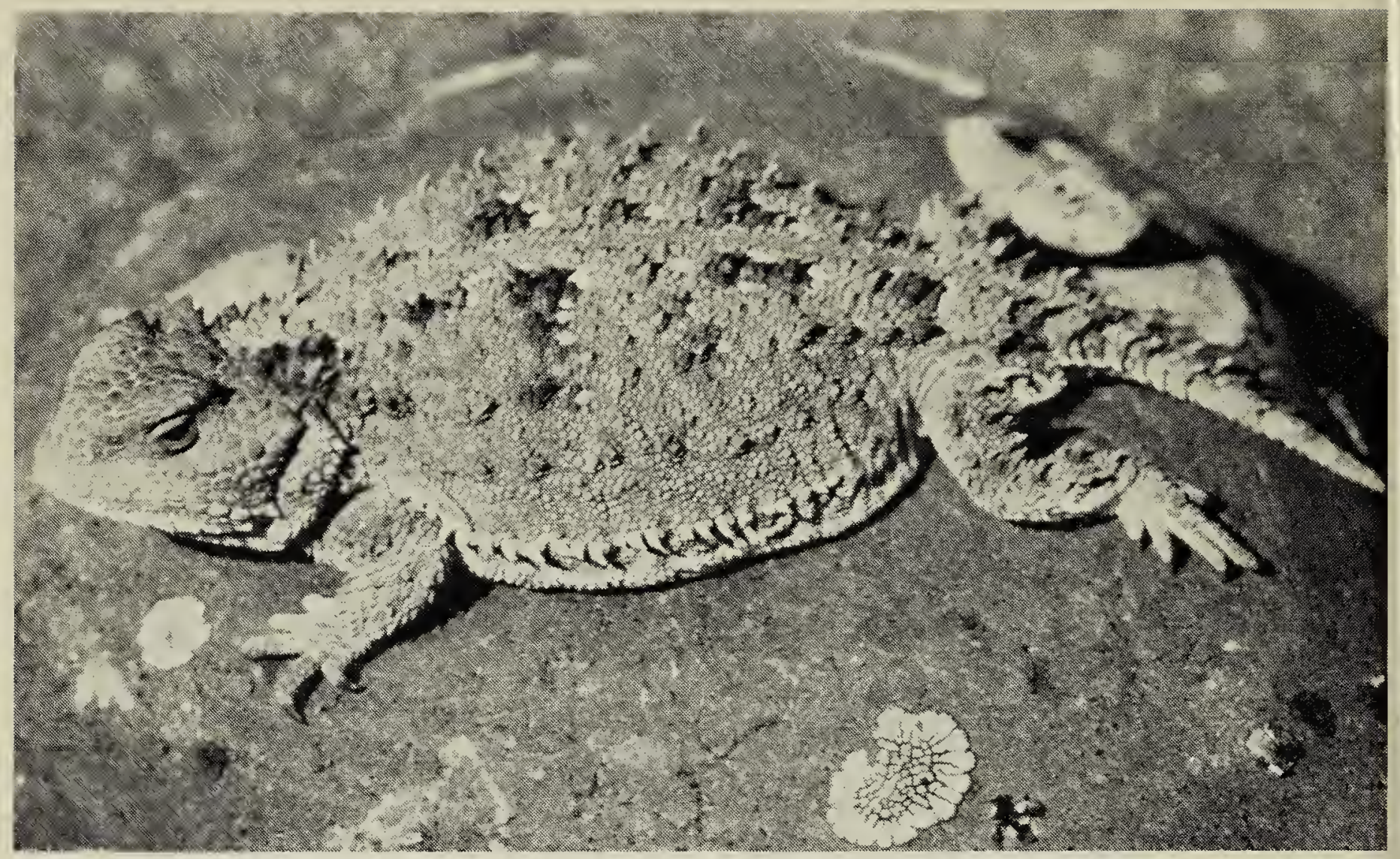

Fred W. Lahrman

\title{
NEW DISTRIBUTION RECORDS \\ OF THE HORNED LIZARD \\ IN ALBERTA
}

DAVID B. SCHOWALTER, Alberta Fish and Wildlife Division, 6909-116 Street, Edmonton, Alberta, T6H 4P2.

Stebbins indicates that the range of the short-horned lizard Phrynosoma douglassi in Alberta includes the area of the Cypress Hills south to the International boundary (Figure 1). ${ }^{1}$ Described here are the first records of the species along the South Saskatchewan River and a new record from along the Milk River.

\section{Locality Data}

SE 24-14-5 W4. Approximately 10 miles northeast of Medicine Hat.

A horned lizard was located by the author and Lorna and Harry Arm- bruster on 16 May 1972 on a southfacing slope in badlands about onequarter mile east of the South Saskatchewan River. Specimen was forwarded to the National Museum of Canada.

24-11-11 W4. Approximately 5 miles northwest of Bow Island.

Four individuals were located by John Gunson and the author 18 August 1976. Three more individuals were located there by the author in 1977. Rod Burns of the Provincial Museum of Alberta collected a specimen at this locality in 1977. Lizards have been found on lightly 
